\title{
THE POSITIVE INOTROPIC ACTION OF INSULIN IN THE CANINE HEART :
}

\author{
Benedict R. I.I!C(HI:SI. Marcelo MLI)INA ** \\ and \\ Frank J. KNIFHEN

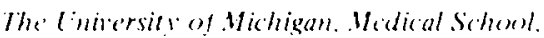

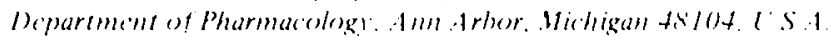

Received 22 Siptember 1971

Accopted 6 binuary 1972

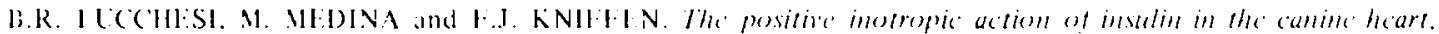
liuropean J. Pharmated. $18(1972) 107115$.

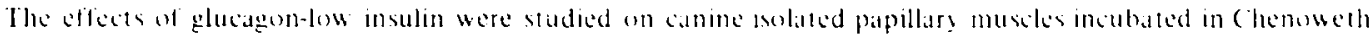
kolle solution and in the pentobarbital anesthetized doge Insulin, 12.5 mbliml. increaned dereloped isometrit tension of papillary muscles which had equilibrated for 17 hrs, but not in muscles incubated up to 60 min. The

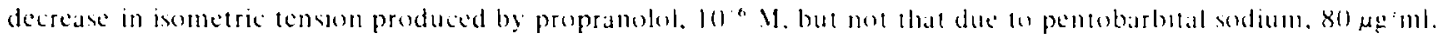

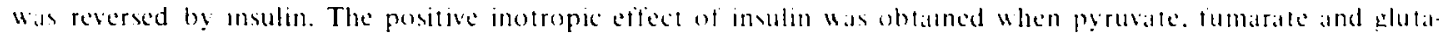
mute replaced glucose as substrate in the chenoueth kolle solution. The intracoronary administratton of insulin. $0.1 \mathrm{l} / \mathrm{kg}$. increased left sentricular isometric tension and the rate of lension development in dog hearts deprensed

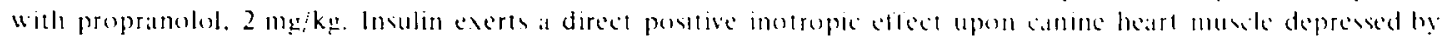

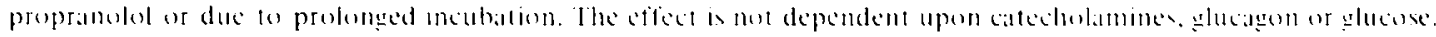

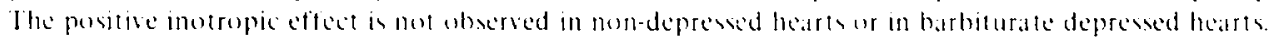

Insulin (glucagon-low)

Propranolol
Heart failure
Inotropic action
Myociardial subctrates

\section{INTRODUCTION}

Farly studies by larah $(1938)$ revealed that certain preparations of insulin produced positive inotropic ef: fects upon the canine heart: an observation which was attributed to contamination of the hormonal preparation by an unknown factor or factors. Similarly. Regan and coworkers (1963), who used a purified preparation of insulin (glucagontree insulin, Fili Lilly). concluded that the pancreatic hormone did not possess inotropic effects when injected into the lelt coronary artery of the anesthetized dog. even

- Thos study Was supported by a Reveirch Giant in Aid trom the Methigan Heart Association.

** 1)r. Marcelo Mledona Was a W.K. Kellogg Foundation L at in American Medical lellow. Present address: Department ot Platmatcology, Instatute of Medical and Bulogemal

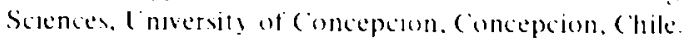

though insulin exhibited its classical elfect on glucose uptake and an increase in the cardiac respiratory quotient.

Renewed interest in the possible inotropic effect of insulin has been stimulated by the studes of SodiPallares et al. (196.3) who have advocited the clinical use of insulin in combination with glucose and $\mathrm{KCl}$ in the management of patients with acute myocardial infarction. A recent study by ('arlstrom and karlefiors (1970) has indicated that cardiac performance was increased in the juvenile diabetic pattent after adequate insulin therapy. Sharma el al. (1970) and Taylor et al. (1969) have reported a suppression of insulin secretion to be associated with heart fallure or myocardial infarction: the therapeutic implications of which should deserve serious consideration since the supression of insulin secretion may possibly aggralvalte the hean failure. Recent studies by Merin $(1070)$ in- 
dicate that insulin couk reverse the myocardial de. pression produced by halothane: an action that was attributed to the ability of insulin to enhance myo. cardial glucose ratnsport. A similar conclusion regarding the inotropic actom of insulin was alrived at by Woisster el al. (1970) who reported that the hormone increased glucose transport and cardiac performante

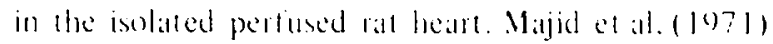
have demensatraded a cortelation between the low cardiac ouput stite and the indbility to secrete insulin in response to the i.x. injection of tolbutamide in pationts after opentheart surgery and suggest that the administration ol insulin maly possibly produce dini(a) improvement.

In vew of the devergent views concerning the indetropic action of insulin and its mechanism. a study Was undertaken to investigate the elteets of the hormone an dog isolated papillary muscles as well as in the antact heart of the dog. The results suggest that insulin is capathle of signilicantly algmenting contractile loree of the depressed myerardium and that the posstive inotropic etfied is not dependent upon increased glucose transpont across the myeradial cell.

\section{MATHRIAISAND WITTIODS}

\subsection{Papillary muscle preparation}

Mongrel dogs. 7 lo kg in weight were antestlee. tised with perlobarbital sodium. $30 \mathrm{mg} / \mathrm{kg}$. i.v. and 90 min were allowed 6 elapse before thoracotomy wals performed. This time interval was considered sutticient lo permit adequate distribution of the barbiturate antesthetic and a reversal of the tansient depression of myocardial contractility that occurs upon the rapid i.r. administration of pentebarbital sodium. The heart was rapidly excised and placed in cooled. oxygensated chensweth Kolle solution. Right ventricular papillary muscles were carrefully selected and mount ed in muscle chambers containing $50 \mathrm{ml}$ of (henoweth kolle solution which was vigorously hubbled with $95: 0_{2} \quad 5: \mathrm{CO}_{2}$ and maintained at a temperalure of $37^{-6}$. The nonemdenous ends of the muscles were held $n$ a Lucite clip and the upper end of the musckes were atlacked by hraded non-capillary silk 11) a FT-0, force displacement transducer. The muscles were strelched by a resting force which was near the peak of ther active lengld tension curves ap- proximalely 2 g) and were maintained at this length throughout the study. The isometrie muscles were stimulated via punctate electrodes with square walve pulses of 0.5 msec duration. at a rate of $60 \mathrm{~min}^{-1}$ with a current 10\%" above theshold deliveled from an 104A American liketronices l abomatories Stimulator. All recordings were made on a Cialss Mudel ? Polygraph. The signal from the force displatement transducer las simultaneously displiyed on a Tektromis 50 A ascilloseope and photographed with a Polatord (almeral.

The muscles were divided into lave groups. Thore of group I were allowed to contract isometrically lor I the before being exposed on insulin. The papillary

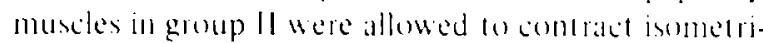
cally for a period of 1 ? he before the addition of insulin. Gmups 1 and 11 muscles will be referred lo als fresh and rilligued muscles. respectively. The cantine papillaty muscles were selected with eate so that only the smallest muscles woukd be used so an fo insure adequate axygetaltion of the muscle. The palpillary musckes varted from 2 $10.3 \mathrm{~mm}$ diameter and were from? 1010 mm m length. The reasum for using the calline preparaltion rather that the all or tabbit wals becillse the latler lwo spectes did thot e hibll an moropie response of insulin. The adequacy of the cantine papillary muscle preparation is show's by the fidet that the muscles contimued to lunction fior periods in excess of $20 \mathrm{hr}$ and responded in a rypical manner wo patred electrical palcing and lo oubbatn.

The composition of the hath medium was at fol.

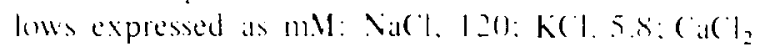

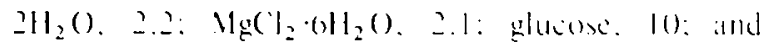
Ville(O) $)_{3}$ 14. The pll was adjusted 10 ?.4. In addition. wo other bath medial were prepared in which the dextrose was reduced lo 1 mill and a solution without dextrose, but w which had been added: pos. tassium pyruvate. 5 mnl. sodium fumarate. 5 mil. and monte-sodium glutamale. 5 mill The hater two solutions atre reterted a respectively a a dextruselow' and a dextrose-fiee solutionl. In all instances trypsintreated bovine insulin. low in glucigon. Wat added to the moscle chamber in combulative denes to altain concentations of $12.5,25.0$, 50.0 and $100 \mathrm{ml}: \mathrm{ml}$. Successive additions of insulin were made al 10 min intervals. Al the conclusion of each experiment lise papillary muscles were subjected to parted-pacing to determine the maximum isometriti 
tension for each muscle. The isometric force responses to insulin were expressed as a percent of the maximum isometric force. The data were analyzed statistically with the standard $t$-test for group comparisons (Snedecor and Cochran. 1967).

\subsection{Intact deg heart preparation}

Male mongrel dogs. between 1.3 and $27 \mathrm{~kg}$. were anesthetized with pentobarbital sodium. $30 \mathrm{mg} / \mathrm{kg}$. i.v. Positive pressure respiration was maintained through an endotracheal tube by a Harvard respirator pump. Systemic arterial pressure was measured from a femoral artery with a Statham pressure transducer. The cervical vagi were severed bilaterally. The heart was exposed through a thoracotomy in the left fifth intercostal space. A $510 \mathrm{~mm}$ segment of the anterior descending branch of the left coronary artery was dissected free near its origin. Heparin was administered in an initial dose of $5 \mathrm{mg} / \mathrm{kg}$ and then in hourly doses of $2.5 \mathrm{mg} / \mathrm{kg}$. The anterior descending coronary artery was cannulated with a polyethylene cannula and perfused from a femoral artery. The blood flow through the descendans branch was maintained constant by a hilateral roller pump. In each experiment the descendans coronary flow was adjusted 10 pro. duce a mean coronary perfusion pressure equal to the mean systemic arterial pressure. Coronary perfusion pressure was measured with a Statham pressure transducer from a sidearm of the coronary artery cannula near the heart. The temperature of the perfusing blood was maintained constant at $37^{\circ} \mathrm{C}$ by means of a heat exchanger interposed beween the perfusion pump and the heart. The temperature was monitored continuously with a thermistor probe inserted into the blood stream near the heart. A calibrated Brodie Walton strain gatuge arch was sutured at the apex of the left ventricle in a region supplied by the anterior descending coronary artery. The peak rate of force development $(\mathrm{dF} / \mathrm{dt})$ was electronically differentiated and recorded simultaneously with isometric ventricular tension on a Grass Model 7 Polygraph.

All drugs were administered either intravenously into a canmulated external jugular vein. or by intracoronary (i.c.) injections via a side arm of the extracorporeal circulation supplying the anterior descend. ing coronary artery.

\section{RESULTS}

\subsection{Effects of insulin upon dog isolated papillar. muscles}

A total of 14 papillary muscles was incubated in Chenoweth Kolle solution containing dextrose in a concentration of $180 \mathrm{mg} /(10 \mathrm{mM})$. The muscles were allowed to contract isometrically for $1 \mathrm{hr}$ before insulin was added to the bath medium. The control developed isometric tension averaged $0.58 \pm 0.11 \mathrm{~g}$ which was $23.4 \pm 2.9 \%$ of the maximum isometric tension developed in response to paired pacing. The addi(ion of insulin. $12.5 \mathrm{~mL} / \mathrm{ml}$. produced an average developed tension of $0.70 \pm 0.15 \mathrm{~g}$ or $29.5 \pm 5.3 \%$ of the maximum developed tension. The insulin-induced change in developed tension. or the mean clange in tension expressed as a percent of the maximum tension, did not differ significantly from the control values $(p>0.05)$. When papillary muscles were allowed to contract isometrically for $17 \mathrm{hr}$ in (henoweth Kolle solution (dextrose. $180 \mathrm{mg}$ or $10 \mathrm{mM}$ ) the developed tension in 10 preparations averaged $0.12 \pm 0.02 \mathrm{~g}$ or $1.3 .1 \pm 3.1 \%$ of the maximum developed isometric tension. The addition of insulin, $12.5 \mathrm{ml}: / \mathrm{ml}$. to the 'fatigued' papillary muscles produced a significant increase in isometric tension as expressed in absolute units or as a percentage of maximum developed tension: $0.24 \pm 0.5 \mathrm{~g}(p<0.025)$ and $21.3 \pm 3.5 \%(p<0.005)$. respectively. Qualitatively similar results were obtained when the dextrose concentration was reduced $1018 \mathrm{mg} \%(1 \mathrm{mM})$ or when the dextrose was eliminated and replaced with pyruvate, fumarate and glutamate. The inotropic response to insulin was observed only in 'fatigued' papillary muscles. The data are summarized in table 1 and the insulin-induced responses upon 'fatigued' papiliary muscles incubated in the presence of $1 \mathrm{mM}$ dextrose (18 $\mathrm{mg} \%$ ) or in the absence of dextrose are shown in figs. I and 2. respectively.

The insert in fig. 1 shows the isometric force re. sponses as recorded from an oscilloscope before and after the addition of insulin to the bath medium. Although insulin increased the developed isometric tension and rate of tension development. it did not alter the time to peak tension or change the duration of the contractile response.

It should be noted that although the papillary muscles were depressed after $17 \mathrm{hr}$ of incubation, in- 
Table 1

leflect of insulin upon canine papillars muscles.

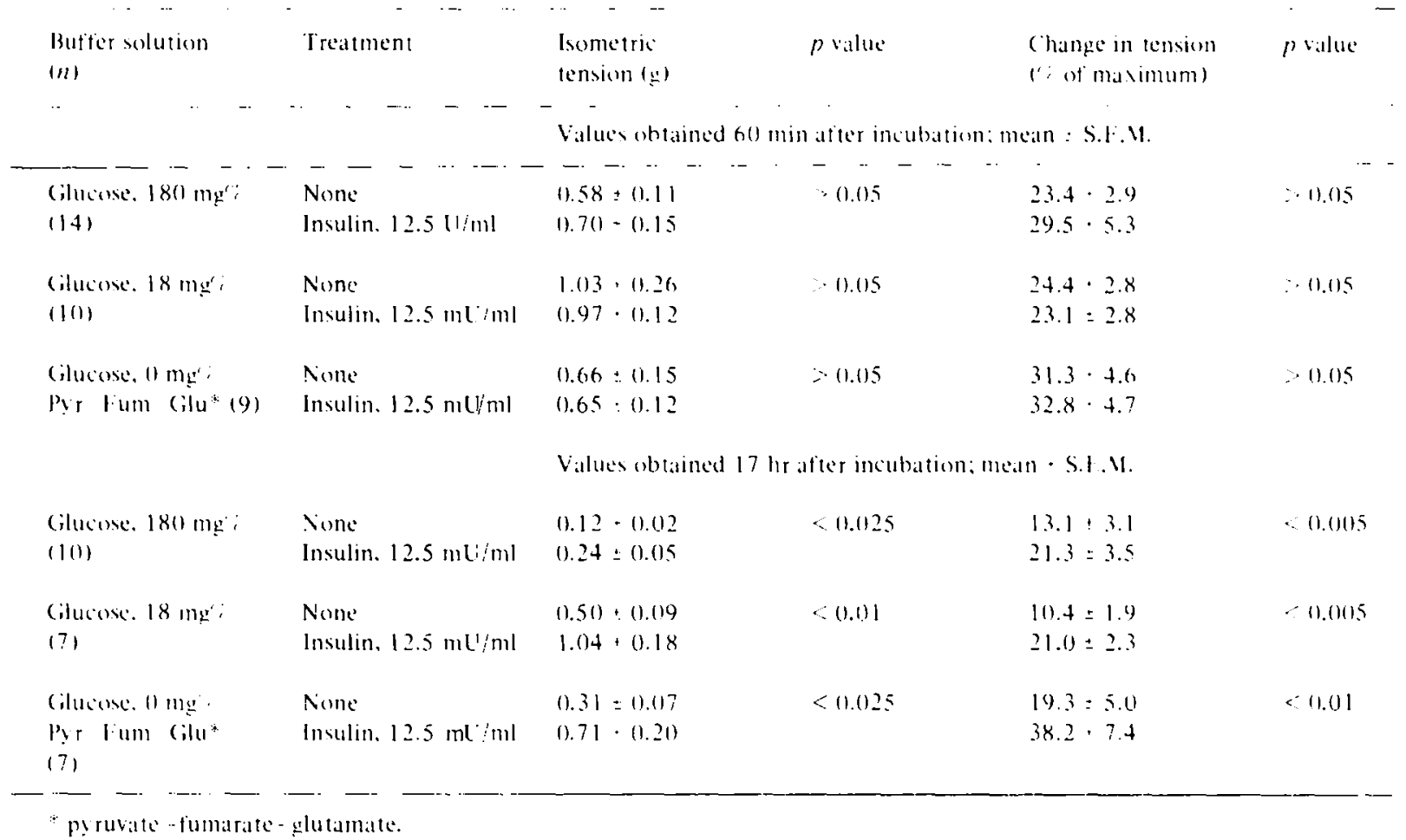

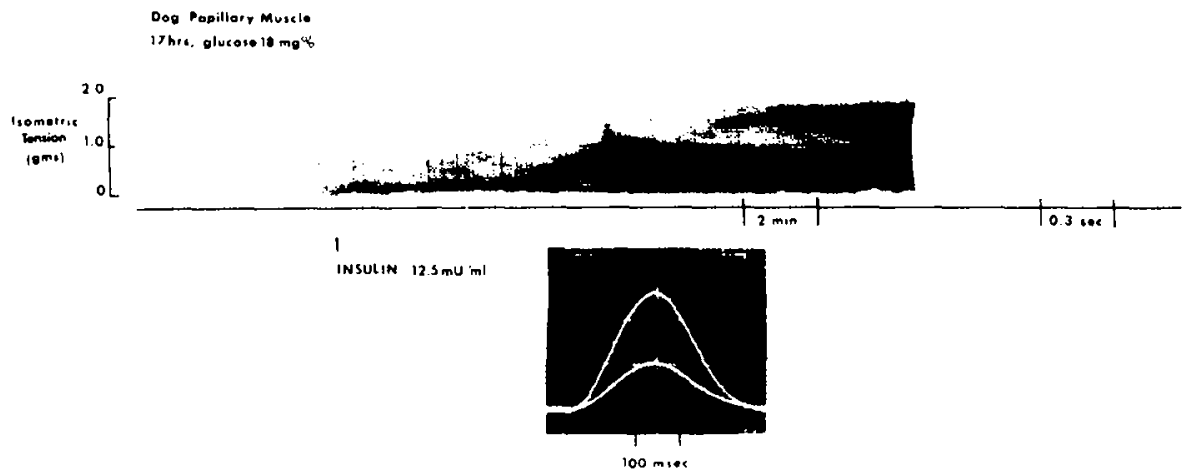

1.ig. 1. Itfect of insulin. $12.5 \mathrm{ml} / \mathrm{mm}$, upon developed isometric tension in the dog papillary muscle incubated fur 17 hr in (henoweth Kolle solution having a glucose concentration of $18 \mathrm{mg}$; $11 \mathrm{~m}$ Ml). The inset at the bottom of the figure is the photographic recording of the isometric contractions recorded from an ascillosiope. The anset of the positive incotropic atfect requires approximately 2 min and reaches a maximum within 10.12 min. Insulin increased the rate of tension development. Without changing the time to peak tension or the duration of the contractile went. 


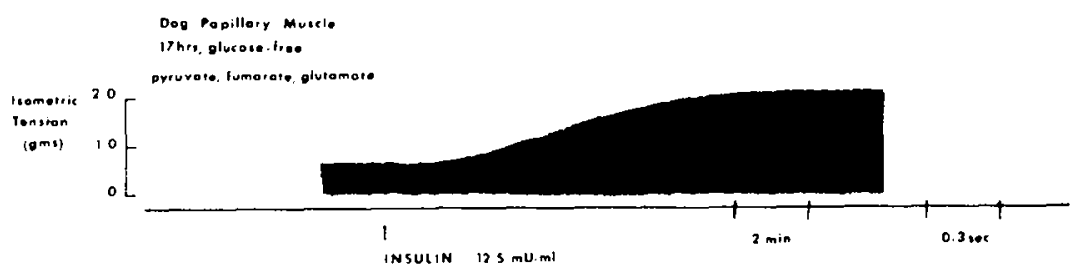

I ig. 2. Helect of insulin. $12.5 \mathrm{mb}$ iml. upon developed isometric tension in the dog papillary muscte incubated for 17 hr in glucose-free chenoweth kolle solution in wheh pyruvate, fumarate and glutamate served as substrates. The contractile response ti) insulin appears within $2 \mathrm{~min}$ and reaches a maximum within $1012 \mathrm{~min}$.

sulin was capable of producing an average isometric force response equal to that produced by papilary muscles incubated for $1 \mathrm{hr}$ in $18 \mathrm{mg}$; glucose or glucose-free Clenoweth Kolle solution. Although insulin produced a positive inotropic effect in 'fatigned' papillary muscles incubated in the presence of $180 \mathrm{mg} \%$ glucose. the magnitude of the response was not as great as that obtained with muscles incubated in the presence of $18 \mathrm{mg}$,' glucose or in the presence of pyruvate. fumarate and glutamate. Therefore, the positive inotropic response 10 insulin was observed only in papillary muscles permitted a contratet conanuously for $17 \mathrm{hr}$ and the insulin-induced response was independent of the presence of glucose in the medium. It was also noted that the response to insulin occurred at a concentration of $12.5 \mathrm{mU} / \mathrm{ml}$. Lower concentrations failed to produce a significant augmentation of contractile force and further increases in the concentration did not produce an add tional increment in isometric tension. The increment in developed tension was sustained and was slowly reversed by washing the muscle for several hours during which time the addition of insulin to the bath failed to initiate a significant positive inotropic response.

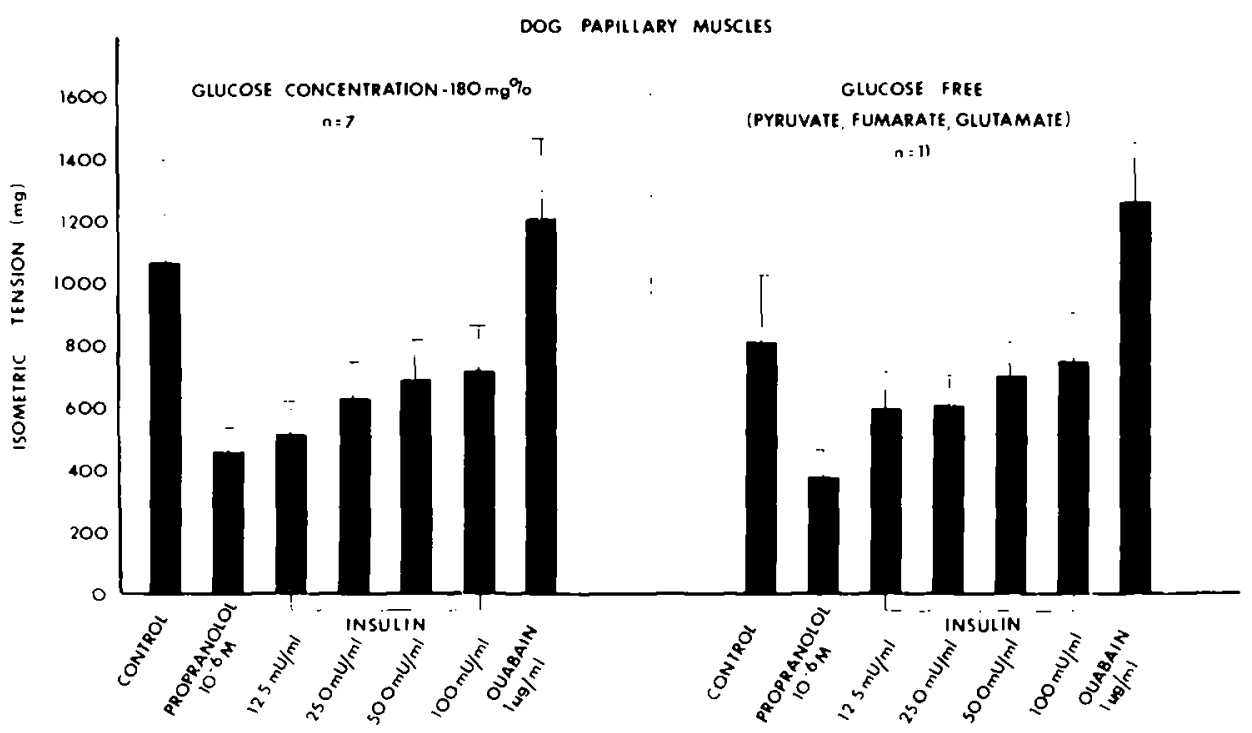

IFig. 3. The effect of insulin on the propranolot-depressed deg papillary muscle. Mluscles were exposed to propranolol. 11 " II. tor $45 \mathrm{~min}$ before the addition of insulan. Lnder these condations, the muscles displityed al dose-dependent response to insulin and a further atgmentation of developed cension an response lo olatain. 


\subsection{Lffect of insulin upon dog isolated papillary mus-} cles depressed with propranolol or pentobarbital sodium

Since the previous studies had suggested that insulin would exert a positive inotropic effect upon 'fatigued' papillary muscles. it was considered important to study the effect of the hormone in the presence of drugs known to produce a depression of myocardial cont ractility.

Recently excised papillary muscles, incubated in the presence of glucose $(180 \mathrm{mg} / \mathrm{s})$ or in a glucosefree medium were exposed to d.1-propranolol. $10^{-6} \mathrm{M}$. for a period of $45 \mathrm{~min}$. The addition of d.1-proprano. (o) resulted in a significant depression of isometric tension. The addition of insulin, $12.5 \mathrm{to} 100 \mathrm{~mL} / \mathrm{ml}$. produced a dose-dependent increase in isometric force in both groups of muscles. An additional incre. ment in isometric tension was achieved by the administration of ouabain. $1 \mu \mathrm{g} / \mathrm{ml}$. The data are presented graphically in fig. 3. Unlike the study in nondepressed papillary muscles. insulin produced an augmentation of eontractility in muscles which had been contracting isometrically for less than 2 hr. but which bad been depressed by d.1.propranolol added to the bath medium. Another point of difference. was the fact that papillary muscles depressed with (llpropranolol exhibited a dose-dependent increase in

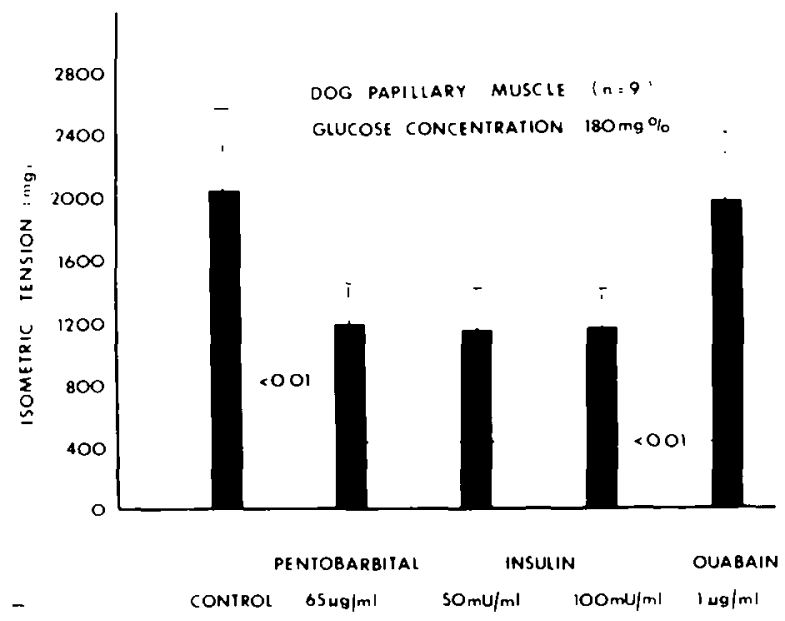

1.ig. 4. The effect of insulin on the pentobarbital-depressed dog papillary muscle. The addition of pentobarbital produced a significant depression in isometric force which ecould not be reversed by insulin. Ouabain. !owever. produced a positive inotropic effect. isometric tension in contra-distinction to 'fatigued" muscles which failed to show a dose-dependent change in developed tension.

The results obtained with insulin in 9 papillary muscles depressed with pentobarbital sodium are shown in lig. 4. L'nlike the previous results, insulin falled to augment the contractility of the pentobarbitaldepressed muscle even though the preparations did exhibit a significant increase in developed isometric force when exposed to ouabain. $1 \mu \mathrm{g} / \mathrm{ml}$.

Insulin heated $10100^{\circ} \mathrm{C}^{\prime}$ at pH 11 for 30 min failed to augment developed isometric force although the subsequent administration of the non-denatured hormone to the isolated muscle produced the typical positive inotropic effect.

\subsection{Lffect of insulin upom the intact canime heart}

Insulin in a dose of $0.1 \mathrm{U} / \mathrm{kg}$ was administered into the anterior descending coronary artery in each of 6 open-chest anesthetized dogs. which had been treated with propranolol. 2 $\mathrm{mg} / \mathrm{kg}$. i.v. In each of the dogs, isometric myocardial force and the rate of tension development $(\mathrm{d} F / \mathrm{d} t)$ recorded from the descendans region were significantly reduced after the administration of propranolol. The subsequent administration of insulin $(0.1 \% / \mathrm{kg})$ directly into the anterior de. scending coronary artery was associated with a positive inotropic effect chatacterized by an increase in isometric force and $\mathrm{d} F / \mathrm{d} t$. The results from one experment are show'n in fig. 5 and the data are summarize: in lig. 6. The mean control \pm S.t.Ml. isometric force and $\mathrm{d} F \mathrm{~d} /$ values were $61.3+0.7 \mathrm{~g}$ and 1801.8 $\pm 264.3 \mathrm{~g} / \mathrm{sec}$. respectively. After propranolol boll values were significantly reduced to $45.0 \pm 3.1 \mathrm{~g}$ and $1128.3 \pm 160.8 \mathrm{~g} / \mathrm{sec}$. Insulin restored both parameters to the control state $61.3 \pm 5.9 \mathrm{~g}$ and $1404.9 \mathrm{t}$ $227.2 \mathrm{~g} / \mathrm{sec}$, respectively. The peak response $10 \mathrm{msu}$. lin occurred within $5 \mathrm{~min}$ and isometric lores and $\mathrm{d} F / \mathrm{d} t$ had returned to the pre-insulin level by the end of $20 \mathrm{~min}$. As observed with the isolated muscle prep. arations. the response $t o$ insulin was delayed and did not begin until 1 or 2 min after administration of the hormone.

In 3 of the experiments summarized in tig. 6. a second strain gauge arch was sutured 10 the right ventricular wall for the measurement of right ventricular isometric force. The positive inotropic response 10 insulin was noted to occur only in the region of the 

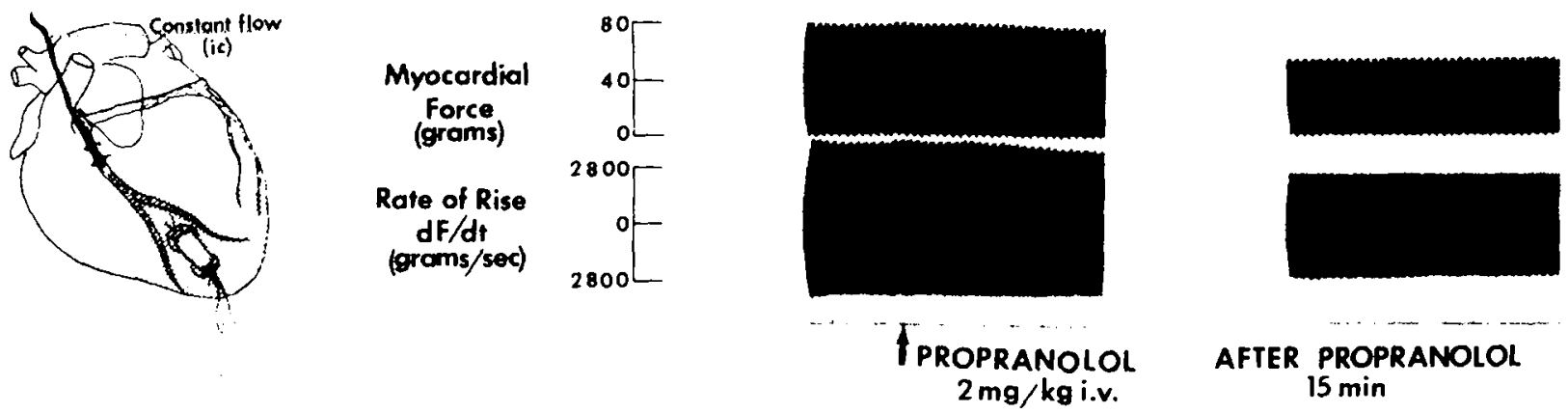

AFTER PROPRANOLOL $15 \mathrm{~min}$
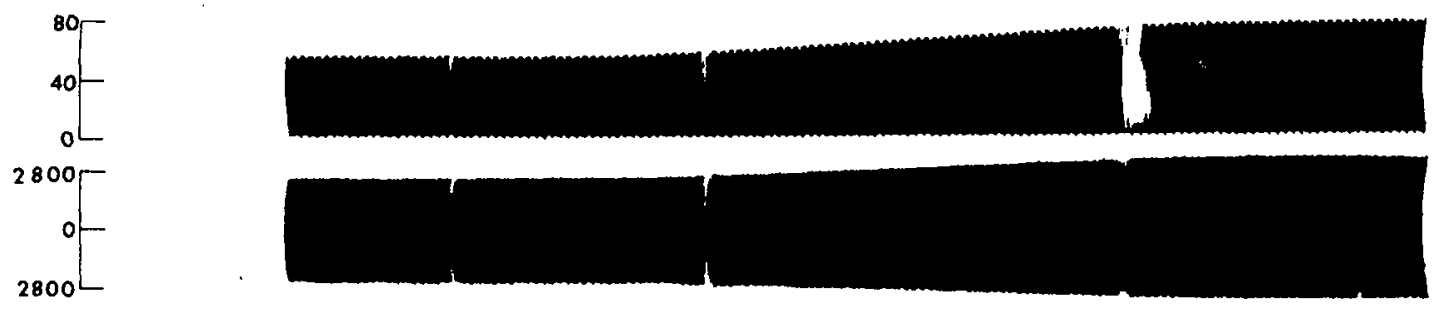

\section{IInsulin $0.1 \mathrm{U} / \mathrm{kg}$ i.c.}

1. ig. S. The reversal of myocardial depression in the intate dog heart by the intracoronary administratuon of insulin (1.l (1/kg. Both

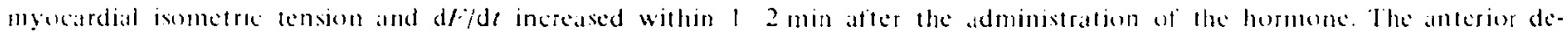
sending coronary artery was supplied with arterlal blood by means af a roller pump and left ventricular isometrie force was recorded from the region of the heart supplied by the anterior descending coronary artery.

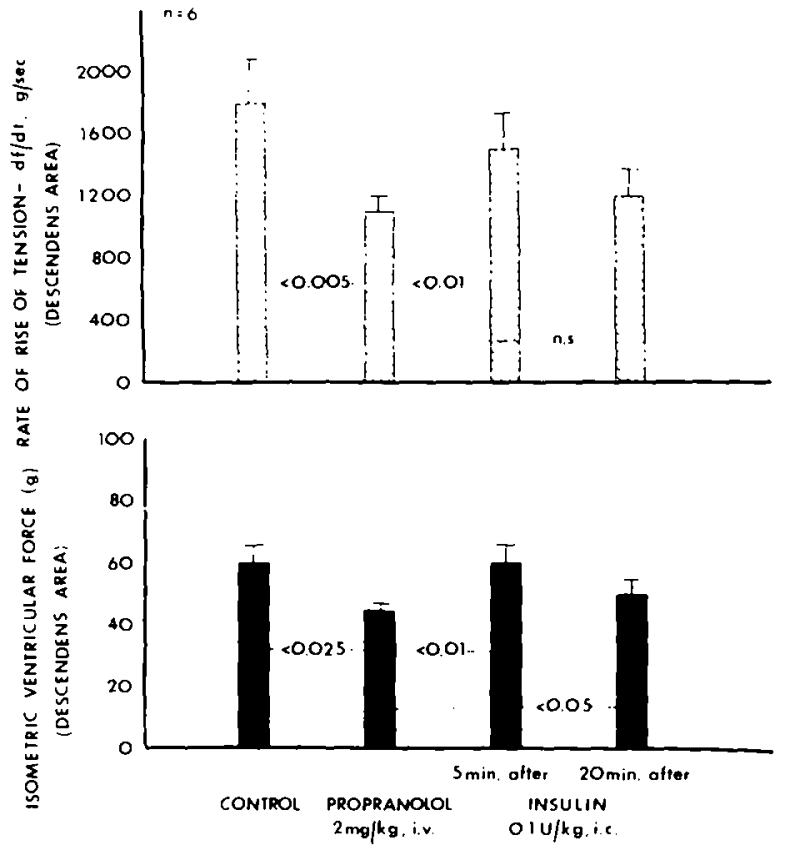

1.ig. 6. Summary of the results obtained in 6 dogs illustrating the positive inotropic action and time course of insulin in the pentobarbital depressed heart. The inotropic response had subsided by the end of $20 \mathrm{~min}$. heart perfused by the anterior descending coronary artery: the ismetric force recorded from the right ventricle did not change after insulin although it was significantly decreased after intravenous administration of propranolol. These results suggest that the positive inotropic action of insulin is the result of a direct effect upon the myocardiam and is not dependent upon the release of neurotransmitters or other biochemical changes brought about by the hormone. Furthermore, the presence of propranolol. 2 $\mathrm{mg} / \mathrm{kg}$. rules out the possibility that the response is due to myocardial $\beta$-idrenergic stimulation. Insulin did not produce any alteration in heart rate which would suggest that glucagon is not involved in the insulininduced response. since glucagon is known to produce both positive inotropic and chronotropic effects.

\section{DISC USSION}

Recent investigations have provided evidence (o) suggest that insulin, by virtue of its ability 10 facilitate glueose transport across the myociardial cell, can 
improve cardiac performance (Sheldon et al. 1960); Merin. 1970: Weissler et al.. 1970; Henderson et al.. 1970). The positive inotropic action of insulin has been demonstrated in the present study in the dog isolated papillary muscle which was allowed to beat continuously for a period of $17 \mathrm{hr}$ at which time the muscles exhibited a marked depression of contractile force. Insulin was capable of restoring the contractile force of depressed muscles to levels of tension devel. opment which approximated those of non-depressed muscles. Papillary muscles incubated for $17 \mathrm{hr}$ in the presence of $180 \mathrm{mg} / \%$ glucose showed a greater degree of depression than did papillary muscles incubated for the same period of time in the presence of I8 mg'; glucose or in the absence of glucose. In the latter instance, tricarboxylic acid metabolites served as substrates. The augmentation of isometric tension upon the administration of insulin was more pro. nounced in the latter two groups, whereas. the positive inolropic response in museles incubated in the presence of $180 \mathrm{mg}^{\prime}$ ir glacose. While statistically significant. never restored tension development to a level comparable to that of non-depressed papillary muscles. The results demonstrate that glucose alone as substrate. in a concentration of $180 \mathrm{mg}$. . is not capable of maintaining the contractile state of the papillary muscles and that contractile performance under these conditions is not restored (o control levels by insulin. In constrast wals the whervation that insulin wats more effective in restoring contractile tension in the absence of extracellulat glucose. These results suggest that the inotropic action of insulin in the depressed papillary muscle is not related to its ability of facilitate the transpor of glucose across the myocardial cell and that the pancreatic hormome may affect wher metabolic processes which alter myocalldial comtatility. Furthermore. the inotropic acton of insulin in the dog papillary muscle is mot demon. strable in recently excised. non-depressed papillary muscle preparations. It should be noted however. that under anderobic conditions the positive inotropic actorn of insulin is observed only when glacose is present in the bathing medium (Macleod and Prusid. $196 \%$ : Praside and Callaghan. $19(90)$ a result which is not une xpected since the glycolytic pathwaly would he the primary source of energy production under conditions of oxygen deprivation. Houneves. the inotropte response to insulin at reported by Maclend and Prasad $\left(1900^{0}\right)$ and Prasad and (allighan $(1960)$ was a minimal effect and did not approach the comractile level which existed in the control state.

It has been suggested that the positive inotropic response to glucose which is further enhanced by insulin accurs in rat heart under conditions in which wygen is limited (Henderson et al. 1970). This is supported by the previously mentioned observations by Macleod and Prasad (1969) and by Prasad and Callaghan $(1969)$. It is doubtful that oxygen limitation was a fiator in the present experiments since the contractile performance of the tatigued papillary muscles was restored to normal upon the addition of insulin in those muscles incubated in $18 \mathrm{mg}$ ir glucose and in the group of muscles incubated in al glucosefree medium in which pyruvate, funarate and glutamate served as suhstrates. It is unlikely that oxygenlimited muscles would have been able 10 arhieve this level of contractike activity let alome survive a contimuous period of stimulation in excess of $17 \mathrm{hr}$. As integrity of cell structure is helieved to be essential for an effect of imsulin. it is mot likely that it would have exerted an effect under prolonged hypoxic conditions. It is unlikely that endogenous lipid serves als an emergy souce for curdiat muscle except during mlense exeresse (Rinelli el al.. 1954) or prolunged fasting (1)enton and Randle. 1967). Therefore. under conditions of high concentrations of extracellular glucose. the need for endogenous lipid as substrate is diminished. The linited effect of insulin under these conditions might be attributed whe filct that its primaly metabolic ation in bringing about at positive inotropie effect does not involve glucose uptake and the glycolytic pathway. The inotropic response is best observed under conditions in which lipid or carbosyl. ic acid metabolism serves as the primary energy source. This sillation would prevail when extacellalar glucose is diminished or absent. It has been icported that glucose uptake by heart muscle is nothmaximal at an extracellular concentration of 5 m:M: but is maximal at $20 \mathrm{mil}$ (Pentey and (asciatino. 1970). The cesults of the present study do nol ruleout the important role of insulin upon glucosc transport. but steggest that a second mechamsm mowing the oxidative pathway might play al signiticanl pan in the hormones inotropic action.

The tailure (o observe an inotropie response (1) insulin in the babiturate depressed hean muscle 
preparation is difficult to explain at present. Similarly. why insulin should reverse the negative inotropic action of propranolol is not clearly understood. Although the effects of propranolol upon myocardial metabolism have not been clearly elucidated. there is some evidence to suggest that propranolol interferes with myocardial lipid metabolism (Satchell et al.. 1968: Nasters and Glaviano. 1969). Furthemore. Bewsher et al. (1960. 1967) have provided evidence 10 suggest that an antogonism exists between insulin and ij-adrenergic receptor blocking agents such as pronethalol and propranolol when stadied upon adipose issue. A similar mechanism may be involved in myocardial tissue and may account for the dosedependent increase in isometric force observed in the propranolol depressed papillary muscle.

The present investigation has demonstrated that glucigon-low insulin is capable of angmenting myocardial contractility in the depressed heart and that the response is not dependent upon the ability of the hormone to facilitate glusose transport across the mycardial cell. The potential therapeutic importance of these observations is suggested by the recent publications in which the role of insulin in heart fallure and in patients with myocardial infarction has been discussed (Carstrom and Karlefors, 1970): Taylor el al. 1969: Sharma el al. 1970; Taylor. 1971: Majid el al. 1971). Thus, insulin may play an important role in maintaining mechanisms of energy production in the failing myocardium and further studies on the metabolic effects of the hormone in experimental congestive heart failure should be undertaken.

\section{RIEILRI:NCIS}

Bewster, P.1). (C. Hillman and J. Ashmure, 1966. Fttects of methalide on insulin activity and binding by rat muscle and adpose tissue, Mol. Phamacol. 2. 227236.

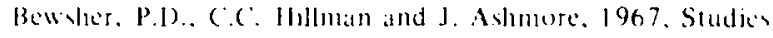
(n) the inhibition of insulin action in vitro bs 3 -adrenergic blocking agents. Ann. N.Y. Acoul. Sci. 139.891896.

(arlstrom. S. and T. Karlefors, 1970. Hacmody namic studies on newly dagnosed diabetics before and atter adequate insulin treatment. Brit. Heart J. 32, 355358.

Dentun. R.M. and P.J. Randle. 1967. Concentration of glys. erides and phowpholipids in rat heart gastrosnemios mos-
Cles. Lifects of allowan diabetes and perfusion. Bochem. J. 10)4. 416,422 .

Furah. A. 1938. Becitratg zut Wirkung des Insulins aus isoliste Abechntle des Dunndarmes, Arch. I Xptl. Path. Pharmak. 188.548553

Henderson, A.H. ed al., 1970 , Iree fatty acids and myocardial lunction in perfused rat hearts. Cardiowas. Res. 4. $466 \quad 472$.

Macleod. D.P. and $k$. Prasild. 1969. Inthence of glucese on the transmembrane action potential of paptlary muxce. J. (ion. l'hysiol. 53.792 815

Matid. P.A. et al. 1971. Insulin secretion atter open-lieart surgery with particular respect on pathogenesis of low cardiac output state, Brit. Heart J. 33.6 11.

Masters, T.N. and V.V. Claviano, 1969. Fifed of d.l-pro. pramoled on myecardial tree tatty actd and carbohydrate metabolism, J. Pharmatol. Faptl. Therap. 167,187-193.

Merin. R.G., 1970. The relationship between myerardial function and glacose in the halothane-depressed heart: Il. the erfect of insulin. Anesthesiologs 33. 396 400.

Penney. 1).(; and J. (atciarano. 1971). Anaterobic rat heart. lfferts of glacoss and tricarbosyliciatid metabolites on metabolism and physological performante. Biochem. I. 118.221227.

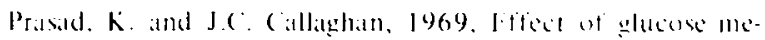
labulism on the transmembrant actun potental and contraction of hy man papillary mascle during vargical anme ia. Amo. Thuracic Surg. 7.571..581.

Regan. T.1. et al. 1963. Relationship of invulan and strophantthidin 60 msecardial metabolism and tumetion, Amer. J. Plyyiol. 205. 7901994

Rinctit. M. et al.. 1954, Myocardial lipids after intene muscular work, (ardiologial 45.296275.

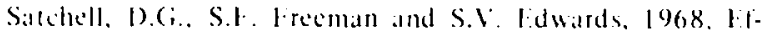
tects of 3-recepter blocking drugs un cardiac metabolism, Burdem. Pharmacol. 17,45 54.

Sharma. B.. el al.. 1970, Insulin secrotion in heart failurs. Brit Med. J. 2. 396398.

Sheldon. M. (i.. M.V. Brambridece and A.J. Coment, 1969. lettect of glucose and insulin on the fatling myocardium in an isolated le:art preparation. Brat. Heart J. 31. 393.

Snedecor, Gill, and 11 . (i. Cochran, 1967. Statistkial methouds

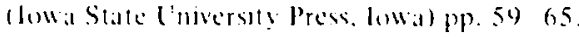

Sodi-Pallares et al. 1963. The polatring tratement of acule myerardial intarction. Possibility of its use in other ciarda-

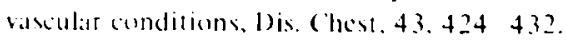

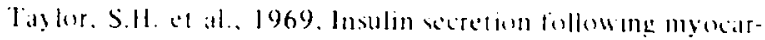
dial intarction with particular resped to the pathogenesis af cardiegenic shock. lancet si. $1373 \quad 1378$

Taylur. S.Ci.. 1971. Insulin and heart fitilure. Brit. Heart J. $33.329 \quad 333$.

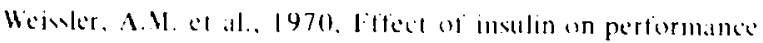
and metabolism of the anovic heart. Circulation 42 . $111 \quad 122$. 